\title{
Declining Carbon Emission/Concentration during COVID-19: A critical review on temporary relief
}

\author{
Arpita Adhikari $^{1 \S}$, Joydip Sengupta ${ }^{2 \S}$ and Chaudhery Mustansar Hussain ${ }^{3 *}$
}

\author{
${ }^{1}$ Department of Electronics and Communication Engineering, Techno Main Salt Lake, \\ Kolkata-700091, India \\ ${ }^{2}$ Department of Electronic Science, Jogesh Chandra Chaudhuri College, Kolkata - 700033, \\ India \\ ${ }^{3}$ Department of Chemistry and Environmental Science, New Jersey Institute of Technology, \\ USA \\ *Corresponding author Email: chaudhery.m.hussain@njit.edu \\ $\S$ These authors contributed equally
}

\begin{abstract}
In December 2019 the deadly pandemic COVID-19 traumatized mankind through its lethal impact. To seize the outbreak, nationwide/region-based lockdown strategies were adopted by most of the COVID-19 affected countries. This in turn resulted in restricted transportation via surface, water, and air, as well as significantly reduced working hours of the industry sectors, so on and so forth. The obvious outcome was a sudden discernible decline in atmospheric adulteration. Accordingly, the anthropogenic emissions at the global and regional/local scales were examined during the lockdown period by several researchers using both or either satellite-based and ground-based monitoring. Among several other air-contaminants, carbon has a dominant toxicological profile causing adverse health effects and thereby attracting researches interest in carbon-release probing during the systematic confinement period imposed by the ruling authorities across the globe. The results of those studies indicated a confirmed decline in carbon emission/concentration making the air more breathable for the period. In this review, the studies related to anthropogenic emissions of carbon during the lockdown period are accounted for by compiling the recently reported data from published articles.
\end{abstract}


Keywords: Carbon emission/concentration; COVID-19; Carbon monoxide; Carbon dioxide; Black Carbon.

\section{Introduction}

Carbon emission had been perhaps pre-historically started since the discovery of fire marking the birth of civilization. An accumulation of the ever-increasing rate of carbon emission/concentrations with the tremendous collective energy demands has led mankind to be affected by its detrimental effect on the environment. Carbon emission/concentration is often stated as one of the main causes of global warming ${ }^{1}$ and also responsible for causing human health hazards affecting cardiovascular, neurological, respiratory complications even leading to death ${ }^{2}$. Amongst different emission sources, the transportation sector has been identified as the major contributor on top of the industry sector in a recent report ${ }^{3}$ based on data of the United States (Fig 1). The current COVID-19 epidemic started at Wuhan, China ${ }^{4}$ in 2019 and spread rapidly across the globe affecting 220 countries ${ }^{5}$. To break the transmission chain, the lockdown was imposed in most of the affected countries around the world, which in turn restricts the vehicle movement ${ }^{6,7}$ and forces most of the industries to remain shut down for the specified period ${ }^{8,9}$. Consequently, the carbon emission originated from vehicles, and the industry sector experienced a sudden reduction. Such occasional depletion in carbon emission/concentration has been reported by several researchers based on numerous studies across the globe. However, to get the complete perception of carbon emission/concentration reduction after the outbreak of the COVID-19 pandemic, the published reports are reviewed here. For the sake of categorical analysis of the reported literature, the review has been performed based on the studies over land and oceanic subdivisions. The published results from the lands are further stratified according to the coverage area as well as the major countries of the globe. 


\section{Total U.S. Greenhouse Gas Emissions by Economic Sector in 2019}

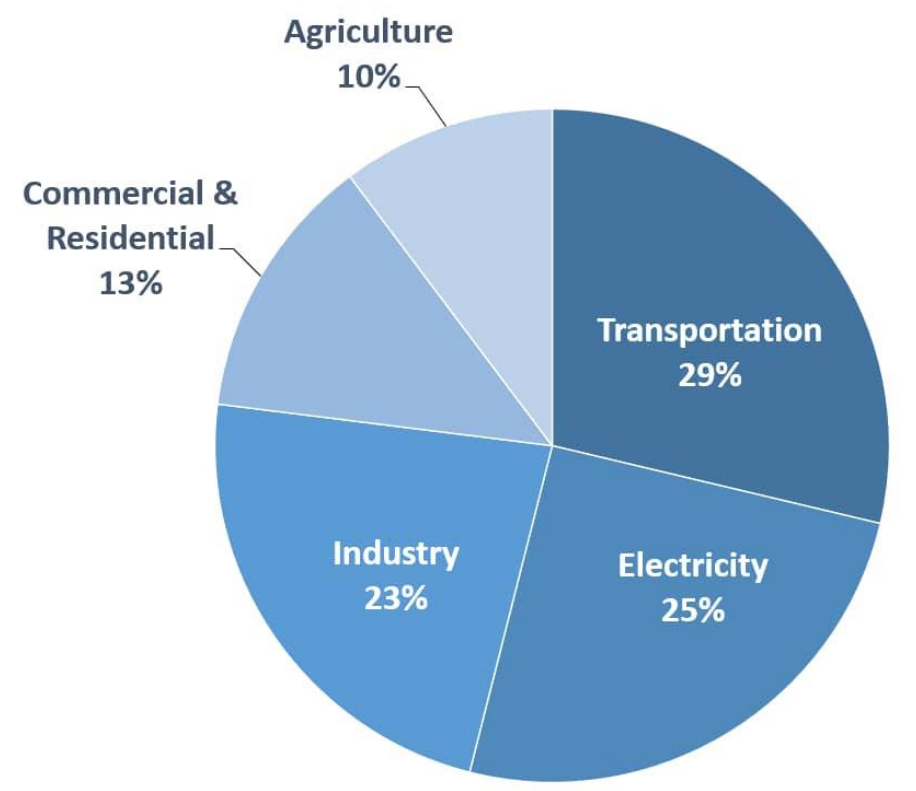

U.S. Environmental Protection Agency (2021). Inventory of U.S. Greenhouse Gas Emissions and Sinks: 1990-2019

Fig 1. Sector-wise greenhouse gas emission. (Reproduced with permission from EPA, USA https://www.epa.gov/ghgemissions/sources-greenhouse-gas-emissions)

\section{Carbon Emission/Concentration over the Land Region}

On the account of the encompassed area over the land region utilized for the study to estimate the carbon emission/concentration, the comprehensive assessment is further sub-divided as cumulative studies, i.e. collecting sample data all over the world, and then as regional studies i.e. collecting sample data from a specific country/region. Initially, the cumulative studies will be discussed and then the regional ones.

\subsection{Cumulative Studies}

In assessing the trend of carbon emission/concentration during the COVID-19 outbreak, several researchers around the earth followed extensive research over the substantial landmass covering several countries of different continents. Liu et al. ${ }^{10,11}$ monitored global 
carbon dioxide $\left(\mathrm{CO}_{2}\right)$ emission of different countries like China, US, India, Japan, Brazil, Russia, Germany, France, Italy, Spain, etc. by collecting near-real-time data from January $1^{\text {st }}$, 2019 to June $30^{\text {th }}, 2020$. The study revealed that there is an abrupt $8.8 \%$ reduction in global $\mathrm{CO}_{2}$ emissions in the first half of 2020 in comparison to the same period of 2019. Quéré et al. ${ }^{12}$ also conducted a similar study and reported that daily global $\mathrm{CO}_{2}$ emissions diminished by $17 \%$ by early April 2020 compared to the mean 2019 levels (Fig 2). Sikarwar et al. ${ }^{13}$ assessed the global carbon emission considering US, EU-28, China, and India. They found that enforced lockdown caused a temporary reduction in anthropogenic $\mathrm{CO}_{2}$ emission by $14 \%$, mainly due to a concurring decrease in surface and air traffic. During the COVID-19 pandemic, the power requirements of the industry sector also declined, which in turn influenced the usual carbon emission. Bertram et al. ${ }^{14}$ found that the COVID-19-induced economic downturn and the corresponding reduction of electricity demand along with the decrease in coal production led to a notable drop of $6.8 \%$ in $\mathrm{CO}_{2}$ emissions across the global power sectors. Evangeliou et $\mathrm{al}^{15}$ examined the change in black carbon (BC) emission over Europe utilizing in-situ observations from 17 European stations in a Bayesian inversion framework. They measured the BC emission during lockdowns and compared the data to the same period in the previous 5 years. They found that BC emissions declined by $23 \mathrm{kt}$ with an average of $11 \%$ across Europe. Impacts on global climate due to the pandemic were estimated by Forster et al. ${ }^{16}$ using data of 123 countries for the period January to June 2020. They also found a sharp fall in $\mathrm{CO}_{2}$ emissions during the lockdown span.

The cumulative studies comprehensively indicate confirmed reduction in carbon emission/concentration during lockdown periods across the globe. 

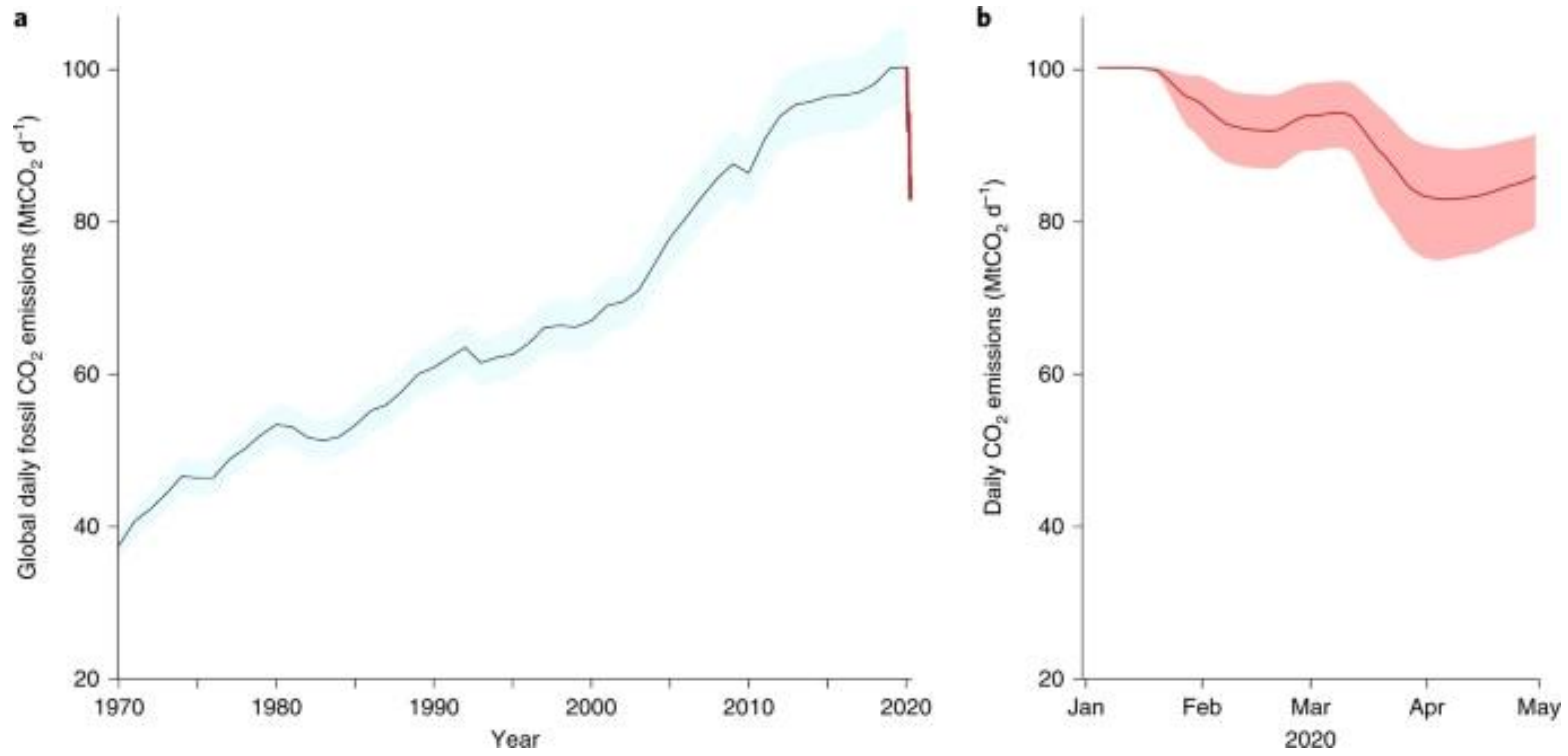

Fig 2. Global daily fossil $\mathrm{CO}_{2}$ emissions $\left(\mathrm{MtCO}_{2} \mathrm{~d}^{-1}\right)$. (Reproduced with permission from Corinne Le Quéré et al., 'Temporary Reduction in Daily Global $\mathrm{CO}_{2}$ Emissions during the COVID-19 Forced Confinement', Nature Climate Change 10, no. 7 (July 2020): 647-53, https://doi.org/10.1038/s41558-020-0797-x)

\subsection{Country-based Studies}

The countries around the world differ widely in terms of annual carbon emission/concentrations. According to the report ${ }^{17}$, China, United States, and India are the top three emitters of $\mathrm{CO}_{2}$. Moreover, the industries and the transportation sectors are found to be the major contributors (> 80\%) of annual $\mathrm{CO}_{2}$ emissions. Consequently, the effect of the enforced shutdown, to combat the COVID-19 pandemic scenario, on carbon emission/concentration are expected to be more significant in the top three countries as mentioned before. Thus the authors selected this under the purview of the present review.

\subsubsection{China}

Owing to the rapid economic development of the world's most populous country, China can be anticipated to experience a substantial decline in carbon emission/concentration during the shutdown session. Zhang et al. ${ }^{18}$ examined the effect of the COVID-19 pandemic on China's 
transportation sector in terms of $\mathrm{CO}_{2}$ emissions (Fig 3). They reported that the COVID-19 had a greater impact on transportation energy consumption and $\mathrm{CO}_{2}$ emissions than SARS. Liu et al. ${ }^{19}$ also estimated the impact of the COVID-19 outbreak on the $\mathrm{CO}_{2}$ emission of China. They found that the reduction in $\mathrm{CO}_{2}$ emission in the first four months of 2020 is 6.9\% compared to the same period in 2019. However, in April 2020, the $\mathrm{CO}_{2}$ emission becomes comparable to the same span of the previous year indicating rapid recovery of China's national economy. Wang et al. ${ }^{20}$ estimated the reduction in $\mathrm{CO}_{2}$ emission in different sectors (industrial, transport, and construction) of China. The investigation showed that net $\mathrm{CO}_{2}$ emissions related to fossil fuel combustion reduced by $18.7 \%$ with significant contributions from industry sectors (12.2\%), transportation (61.9\%), and construction (23.9\%). Han et al. ${ }^{21}$ assessed the effect of COVID-19 on carbon emission based on the domestic data of China. The assessments indicate a fall of $11.0 \%$ in $\mathrm{CO}_{2}$ emissions where ground transport made the most significant contribution $(25.0 \%)$. Zheng et al. ${ }^{22}$ monitored the alterations in anthropogenic emissions of China from January to March in 2020. They found that the $\mathrm{CO}$ emission was much lower in comparison to the previous year within the same span and noted that the lowest emission was recorded in February (28\%) 2020. In another study $^{23}$, they have employed satellite-based data between January and April 2020 and estimated that China's $\mathrm{CO}_{2}$ emissions reduced by $11.5 \%$ in comparison to the same period in 2019. The study of Tohjima et al. ${ }^{24}$ reported $\mathrm{CO}_{2}$ emission in China from February to March 2020 based on 25 years of data from a weather station located at Hateruma Island. The analysis depicted a drop of $32 \pm 12 \%$ and $19 \pm 15 \%$ in China's fossil-fuel-combustion-based $\mathrm{CO}_{2}$ emissions during February and March 2020, respectively.

Zhou et al. ${ }^{25}$ studied the change in carbon monoxide $(\mathrm{CO})$ concentration in 1375 sites of China during lockdown employing surface-based and satellite-based observations. They found that the average $\mathrm{CO}$ surface concentration was reduced by $18.7 \%$ with a spatial 
variation of $8-27 \%$. Zhang et al. ${ }^{26}$ monitored the air quality in China during the COVID-19 pandemic covering 367 cities from 23 January 2020 to April 22, 2020. Their study revealed that $\mathrm{CO}$ concentration dropped by $30 \%$ due to the adopted traffic restriction to cease the spread of viral transmission. Xu et al. ${ }^{27}$ investigated the quality of air of central China during the pandemic from January to March 2017-2020. They observed a 27.9\% decrease in CO concentration in three cities, namely, Wuhan, Jingmen, and Enshi. Xu et al. ${ }^{28}$ studied the BC concentration in the megacity Hangzhou, China, and found a $44 \%$ reduction. Bai et al. ${ }^{29}$ examined the air quality during the lockdown in Shanghai Municipality, China in the period 25 November 2019 to 22 May 2020. They found a steady reduction in CO concentration in the city during the lockdown period. Spatiotemporal variations of air pollutants were studied by Yuan et al. ${ }^{30}$ from January to March 2020 at megacity Hangzhou, China. Their result exhibited that $\mathrm{CO}$ concentration was reduced by $30 \%$ in comparison to the normal period. 


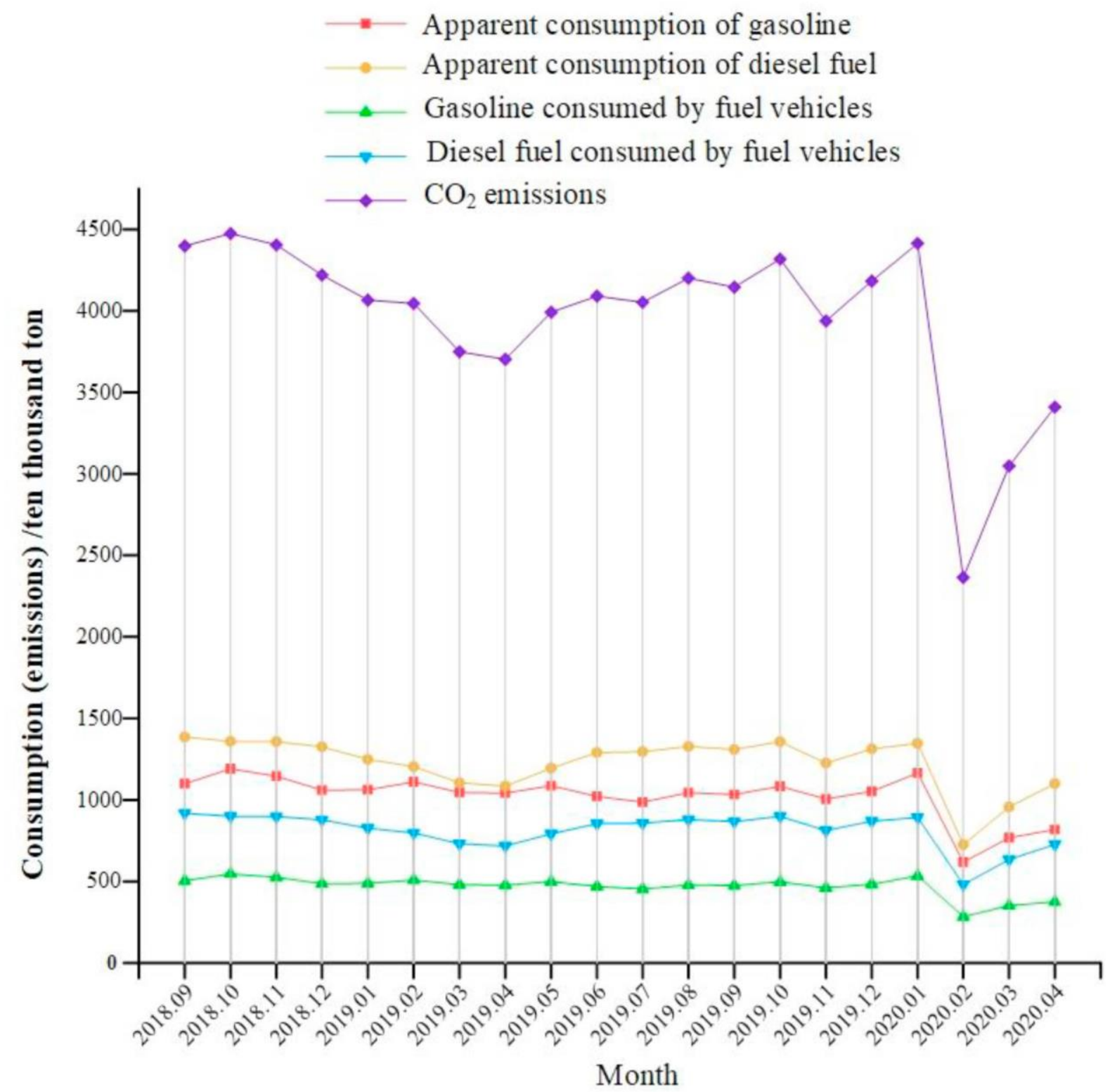

Fig 3. Variation trend of apparent consumption of fuel, fuel consumed by fuel vehicles, and $\mathrm{CO}_{2}$ emissions from September 2018 to April 2020. (Reproduced with permission from Xinxin Zhang, Zhenlei Li, and Jingfu Wang, 'Impact of COVID-19 Pandemic on Energy Consumption and Carbon Dioxide Emissions in China's Transportation Sector', Case Studies in Thermal Engineering 26 (1 August 2021): 101091, https://doi.org/10.1016/j.csite.2021.10109)

\subsubsection{United States}

The United States ranks second in annual carbon emission and accordingly attracts researchers' attention towards the probable decline in carbon emission/concentration during 
the period of Government imposed shut down to prevent the pandemic from spreading. Carbon emissions from different sectors such as commercial, transport, industrial, residential and, electric power sector during the outbreak of COVID-19 had been reported by Aloal et al. ${ }^{31}$. The study revealed that carbon emission was reduced in most of the sectors during the lockdown.

The consistently declining trend of $\mathrm{CO}$ concentration was reported from 28 long-term air quality stations across the U.S. from March 15 to April 25, 2020, by Chen et al. ${ }^{32}$. Elshorbany et $a{ }^{33}$ used the remote sensing method to evaluate the concentration of $\mathrm{CO}$ in New York, Illinois, Florida, Texas, and California. Their study concluded that CO concentration reduced in most of the places. They also reported that in the presence of other sources of carbon emission excluding vehicles, the trend of reduction in carbon concentration may vary from place to place. Hudda et al. ${ }^{34}$ studied the concentration of $\mathrm{BC}$ from vehicles in an urban area of the USA where vehicles are the main source of air pollution (Fig 4). They carried out the study in a mixed commercial-residential neighbourhood in Somerville between March 27 and May 14,2020 . The study revealed that BC concentration was reduced by $22-46 \%$ based on the type of roads. 


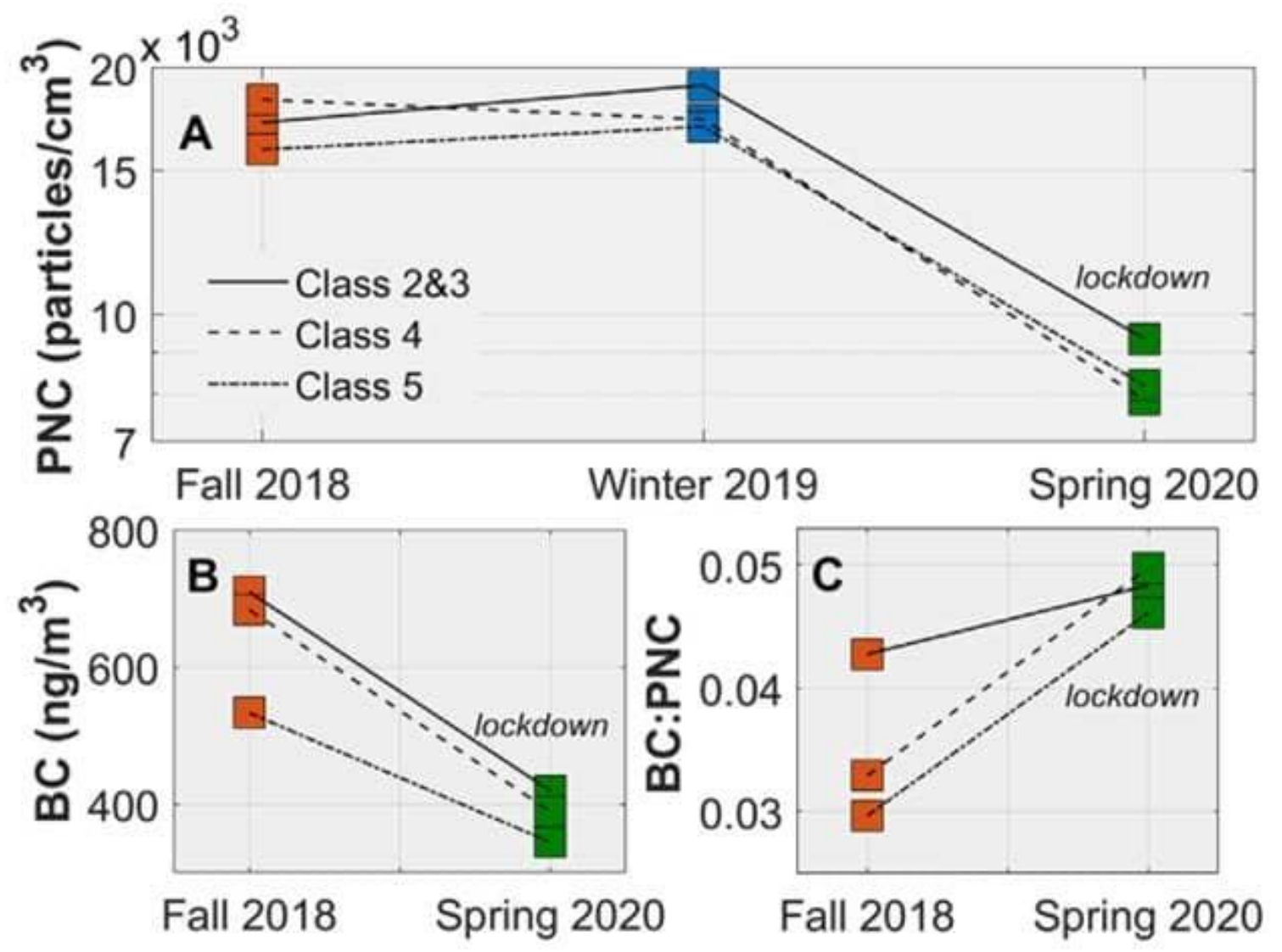

Fig 4. Seasonal medians for (A) PNC, (B) BC, and (C) concentration ratios (BC [ng/m3]:PNC[particles/cm3]) for different roadway classes in the study area. Each colored square represents the seasonal median of the median value of all measurements during a single lap of the monitoring route for each roadway class. (Reproduced with permission from Neelakshi Hudda et al., 'Reductions in Traffic-Related Black Carbon and Ultrafine Particle Number Concentrations in an Urban Neighborhood during the COVID-19 Pandemic', Science of The Total Environment 742 (10 November 2020): 19, https://doi.org/10.1016/j.scitotenv.2020.140931)

\subsubsection{India}

India is the second-highest populated country in the world. Being a developing country, the nation has a major emerging economy, the impact of which led to a concerning increase in annual carbon emission and thereby contributing to the climate crisis. Several studies have been reported in recent days to account for the effect of COVID-19 related shutdown on the variability of greenhouse gases, particularly, on carbon emission/concentration.

Along with the pan-India-based investigation on the effect of lockdown on carbon emission, several local/city-based studies are also reported. Ambade et al. ${ }^{35}$ had followed 


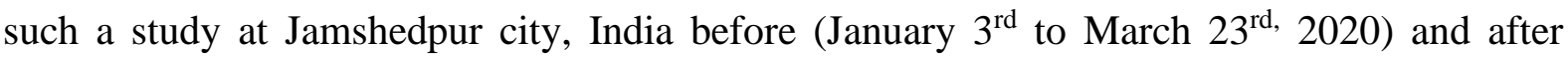
lockdown (April $1^{\text {st }}$ to June $\left.14^{\text {th }}, 2020\right)$ monitoring the reduction in BC during the lockdown. Their result depicted nearly $80 \%$ reductions in $\mathrm{BC}$ emissions because of diminished fuel consumption and a sufficient decrease in other emission sources. In another study by the same group ${ }^{36}$, it was revealed that the $\mathrm{BC}$ concentration started to rise again as the restrictions were withdrawn during the unlock phases. Ajay et al. ${ }^{37}$ studied $\mathrm{BC}$ emission from 2015 to May 2020 at a rural location Challakere, located $230 \mathrm{~km}$ northwest of Bengaluru, India. They found that the lockdown has a very marginal impact on $\mathrm{BC}$ emission at Challakere because the anthropogenic emission from vehicles or industry is very minimal at such a remote site. The same group ${ }^{38}$ also studied the trends in carbon emissions in the megacity of Bengaluru, India during the span from 01 January to 25 May 2020. The results depicted a $60 \%$ reduction in $\mathrm{BC}$ emission due to lockdown. The two studies performed by this group indicated that the reduction in carbon emission is more significant in the urban/city area where anthropogenic emissions are mostly related to the transportation and industry sectors.

The BC concentration over Delhi, India from $18^{\text {th }}$ February to $31^{\text {st }}$ July, 2020 (Fig 5) was monitored by Goel et al. ${ }^{39}$. Their measurements unfolded a constant reduction in BC concentration during Government adopted restriction phases with a maximum recorded reduction of $78 \%$. Sharma et al. ${ }^{40}$ examined the result of lockdown caused by the COVID-19 pandemic in India on air quality in 22 cities from March $16^{\text {th }}$ to April $14^{\text {th }}$ pertaining to the years 2017 to 2020 . The authors reported a $10 \%$ overall decrease in $\mathrm{CO}$ concentration as a consequence of lockdown. Prakash et al. ${ }^{41}$ used satellite-based data to study the environmental impact of pandemic led lockdown in Delhi, Mumbai, Bengaluru, Chennai, and Kolkata, for March and April in 2019 and 2020. The general trend showed that CO concentration decreased during lockdown however, due to the presence of anthropogenic sources other than vehicles and factories, they also observed some spatio-temporal variations. 
Among different sectors, the transportation sector was most badly affected due to the restrictions of lockdown. Gupta et al. ${ }^{42}$ studied the lockdown effect on the air quality in India and reported that $\mathrm{CO}$ levels have been reduced to $10 \mathrm{ppm}$. $\mathrm{BC}$ concentration over the entire land area of India was measured by Gogoi et al. ${ }^{43}$ using the Aerosol Radiative Forcing over India NETwork (ARFINET). The measuring stations are spread all over India and belong to different altitudes. They found that during the lockdown period the $\mathrm{BC}$ concentration reduced significantly across entire India. Moreover, the reduction rate is much higher at urban locations (40\%) than at rural and remote locations (10\%). Eregowda et al. ${ }^{44}$ conducted a study to analyze carbon concentration from vehicle movement before and during the lockdown in four major IT hubs of India, namely, Bengaluru, Chennai, Hyderabad, and Pune. The results showed that there is a sharp drop in $\mathrm{CO}$ concentration by $27.6,13.4,9.8$, and $37.1 \%$ in Bengaluru, Chennai, Hyderabad, and Pune, respectively, as most of the IT companies opted for a work-from-home culture during the lockdown. Both surface and satellite-based observations are utilized by Sathe et al. ${ }^{45}$ to examine the carbon concentration pattern over India from $1^{\text {st }}$ January to $17^{\text {th }}$ May of the years 2017-2020. They used national, regional, and local level data to enhance the accuracy of the observations. Their findings revealed that the $\mathrm{CO}$ concentration, reduced all over India by $16-46 \%$. Bera et al. ${ }^{46}$ measured the impact of COVID-19 lockdown on the CO concentration at megacity Kolkata, India from $25^{\text {th }}$ March to $15^{\text {th }}$ May 2020, and compared it to 3 previous years (2017-2019). Their study exhibited a significant reduction in $\mathrm{CO}$ concentration during the lockdown period with a maximum decrease (-6.88\%) in May 2020.

The studies reported from different corners of the nation are quite substantial and also meticulous in exploring the distinct trends of carbon emission/concentration in different regions of India characterized by dissimilar anthropogenic resources. Such scientific reports 
are crucial for the practical implementation of climatic pollution-control schemes with moderate flexibility based upon the location of execution.

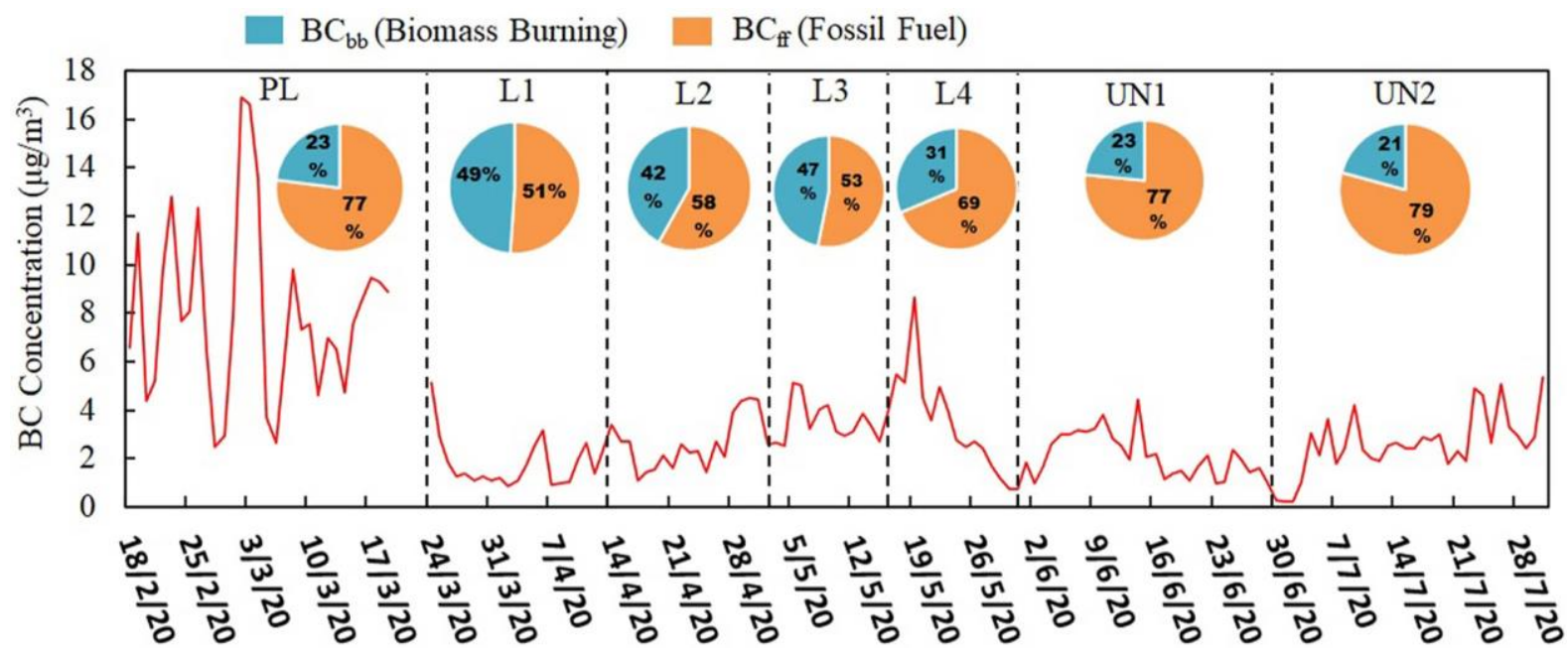

Fig 5. Temporal variation of BC mass concentration. (Reproduced with permission from Vikas Goel et al., 'Variations in Black Carbon Concentration and Sources during COVID-19 Lockdown in Delhi', Chemosphere 270 (1 May 2021): 129435, https://doi.org/10.1016/j.chemosphere.2020.129435.)

\subsubsection{Other Countries}

There are some reports from other countries regarding the studies related to carbon emission/concentration during the COVID-19 pandemic and their subsequent effects. Venturi et al. ${ }^{47}$ measures the effect of the outbreak of COVID-19 on the level of $\mathrm{CO}_{2}$ in the urban region of Italy named Florence. Using the eddy covariance technique they measured atmospheric $\mathrm{CO}_{2}$ concentrations before, during, and after the national lockdown period. A detailed analysis of the obtained data exhibited that $\mathrm{CO}_{2}$ concentrations decreased $62 \%$ during the lockdown phase while enhancement of the same was observed with the resumption of traffic. Numerous environmental aspects were studied by Ali et al. ${ }^{48}$ across Pakistan and measured their change during the COVID-19 pandemic using satellite data. They compared the concentration of atmospheric CO during the lockdown in 2020 with the same period in 2019 and found that atmospheric CO concentration significantly decreased over all the 
megacities. Kanniah et al. ${ }^{49}$ studied the effect of COVID-19 at several stations across Malaysia on different atmospheric parameters including $\mathrm{CO}$ concentration. They found that in the urban and suburban regions the reduction in $\mathrm{CO}$ concentration is much higher than in rural sites. The effect of COVID-19 lockdown on the air pollution level in Korea was examined by Ju et al. ${ }^{50}$ and found that the concentration of $\mathrm{CO}$ was decreased by $17.33 \%$ due to a reduction in domestic sources.

\section{Carbon Emission/Concentration over the Sea}

There exist very few studies conducted over the sea region regarding the effect of COVID-19 outbreak-stimulated lockdown phases on carbon emission/concentration. Grados et al. ${ }^{51}$ illustrated such an estimation of carbon emission over the sea region of Spain (Strait of Gibraltar) during the COVID-19 pandemic situation. Their study revealed that $\mathrm{CO}_{2}$ emission decreased by a minimum of $10 \%$ in comparison to the previous records. However, Al Shehhi et al. ${ }^{52}$ reported the effect of COVID-19 in the sea region globally. Their data evidenced a reduction of $7 \%$ in $\mathrm{CO}_{2}$ emissions. Despite the scarcity of over-the-sea observations reported during the imposed restrictions of the COVID-19 pandemic, the fact-findings are ample enough to discernibly portray the distinguishable characteristics of carbon emission over land and sea.

\section{Summary and Future Outlook}

The COVID-19 pandemic around the world threatened the social pace of human life, unlike ever before. Moreover, the viral outbreak compelled mankind to encounter unprecedented situations like the complete shutdown of all kinds of social activities at different corners of the earth. The adopted restrictions to break the chain of transmission of the disease stirred up the escalating fear of livelihood loss and economic downturn due to the sudden and repeated approaches of close-down of all sorts of transportation as well as industry sectors in the 
strictest means. Despite the darkest impacts of the pandemic, such systematic curtailment turned out to be a blessing to the environment by causing a rapid dip in the ever-increasing trend of carbon emission/concentration. Several studies were conducted across the globe on carbon emission/concentration during the lockdown period to estimate the effect of lockdown (Table 1).

Table 1: Summary of carbon emission/concentration-related studies during the COVID-19 pandemic.

\begin{tabular}{|c|c|c|c|c|c|c|c|}
\hline $\begin{array}{l}\text { SI } \\
\text { N } \\
0\end{array}$ & $\begin{array}{l}\text { Measured } \\
\text { Parameter } \\
(\mathrm{BC} / \mathrm{CO} / \\
\left.\mathrm{CO}_{2}\right)\end{array}$ & $\begin{array}{l}\text { Facility used primarily (for } \\
\text { measurement/as data source) }\end{array}$ & $\begin{array}{l}\text { Duratio } \\
\mathrm{n} \text { of } \\
\text { measur } \\
\text { ement }\end{array}$ & $\begin{array}{l}\text { Place/A } \\
\text { rea/Re } \\
\text { gion of } \\
\text { measur } \\
\text { ement }\end{array}$ & $\begin{array}{l}\text { Change } \\
\text { in } \\
\text { emissio } \\
\mathrm{n}\end{array}$ & $\begin{array}{l}\text { Change } \\
\text { in } \\
\text { concen } \\
\text {-tration }\end{array}$ & $\begin{array}{l}\text { Ref } \\
\text { No }\end{array}$ \\
\hline 1 & $\mathrm{CO}_{2}$ & $\begin{array}{l}\text { Carbon Monitor } \\
\text { (https://carbonmonitor.org) }\end{array}$ & $\begin{array}{l}1^{\text {st }} \\
\text { January } \\
2019 \text { to } \\
30^{\text {th }} \\
\text { June202 } \\
0\end{array}$ & Global & $\begin{array}{l}-8.8 \% \\
(-1551 \\
M t)\end{array}$ & & [10] \\
\hline 2 & $\mathrm{CO}_{2}$ & $\begin{array}{l}\text { Carbon Monitor } \\
\text { (https://carbonmonitor.org) }\end{array}$ & $\begin{array}{l}1^{\text {st }} \\
\text { January } \\
2019 \text { to } \\
30^{\text {th }} \\
\text { April } \\
2020\end{array}$ & Global & $-17 \%$ & & [12] \\
\hline 3 & $\mathrm{CO}_{2}$ & $\begin{array}{l}\text { International Energy } \\
\text { Agency(https://www.iea.org) } \\
\text { and Carbon Monitor } \\
\text { (https://carbonmonitor.org) }\end{array}$ & $\begin{array}{l}\text { January } \\
\text { to April } \\
\text { (2019 - } \\
\text { 2020) }\end{array}$ & Global & $\begin{array}{l}-14 \% \\
(-1749 \\
M t)\end{array}$ & & [13] \\
\hline 4 & $\mathrm{CO}_{2}$ & $\begin{array}{l}\text { International Energy Agency } \\
\text { (https://www.iea.org) and bp } \\
\text { (https://www.bp.com) and } \\
\text { Ember (https://ember- } \\
\text { climate.org) }\end{array}$ & $\begin{array}{l}\text { January } \\
\text { to } \\
\text { Septem } \\
\text { ber } \\
(2019 \text { - } \\
2020)\end{array}$ & Global & $-6.8 \%$ & & [14] \\
\hline
\end{tabular}




\begin{tabular}{|c|c|c|c|c|c|c|}
\hline 5 & $\mathrm{BC}$ & $\begin{array}{l}17 \text { European stations } \\
\text { (https://www.actris.eu) } \\
\text { and accent-network } \\
\text { (http://www.accent- } \\
\text { network.org) } \\
\text { and Nasa } \\
\text { (https://disc.gsfc.nasa.gov) }\end{array}$ & $\begin{array}{l}2015 \text { to } \\
31^{\text {st }} \\
\text { April } \\
2020\end{array}$ & Global & $\begin{array}{l}-11 \%(- \\
23 \mathrm{kt})\end{array}$ & [15] \\
\hline 6 & $\mathrm{CO}_{2}$ & $\begin{array}{l}\text { NBS , China } \\
\text { (http://www.stats.gov.cn/englis } \\
\text { h/)and https://oil.chem99.com }\end{array}$ & $\begin{array}{l}01^{\text {st }} \\
\text { Septem } \\
\text { ber } \\
2018 \text { to } \\
31^{\text {st }} \\
\text { August } \\
2020\end{array}$ & China & $\begin{array}{l}-46.45 \\
\%\end{array}$ & [18] \\
\hline 7 & $\mathrm{CO}_{2}$ & $\begin{array}{l}\text { Carbon Monitor } \\
\text { (https://carbonmonitor.org) }\end{array}$ & $\begin{array}{l}\text { January } \\
\text { to May } \\
(2019 \text { - } \\
\text { 2020) }\end{array}$ & China & $-6.9 \%$ & [19] \\
\hline 8 & $\mathrm{CO}_{2}$ & $\begin{array}{l}\text { Carbonbrief } \\
\text { (https://www.carbonbrief.org) } \\
\text { and NBS, China } \\
\text { (http://www.stats.gov.cn/englis } \\
\text { h/) }\end{array}$ & $\begin{array}{l}\text { January } \\
\text { to April } \\
\text { (2019 - } \\
\text { 2020) }\end{array}$ & China & $-18.7 \%$ & [20] \\
\hline 9 & $\mathrm{CO}_{2}$ & $\begin{array}{l}\text { NBS, China } \\
\text { (http://www.stats.gov.cn/englis } \\
\text { h/) and Wind } \\
\text { (https://www.wind.com.cn/en/ } \\
\text { edb.html) }\end{array}$ & $\begin{array}{l}\text { January } \\
\text { to April } \\
\text { (2019 - } \\
\text { 2020) }\end{array}$ & China & $\begin{array}{l}-11.0 \% \\
(-257.7 \\
M t)\end{array}$ & [21] \\
\hline 10 & $\mathrm{CO}$ and $\mathrm{BC}$ & $\begin{array}{l}\text { NBS , China } \\
\text { (http://www.stats.gov.cn/englis } \\
\text { h/) and Tomtom } \\
\text { (https://www.tomtom.com/en } \\
\text { gb/traffic-index/) and } \\
\text { Copernicus }\end{array}$ & $\begin{array}{l}01^{\text {st }} \\
\text { January } \\
2019 \text { to } \\
31^{\text {st }} \\
\text { Decemb }\end{array}$ & China & $\begin{array}{l}-5 \% \\
(\mathrm{CO}) \\
-4 \%(\mathrm{BC})\end{array}$ & [22] \\
\hline
\end{tabular}




\begin{tabular}{|c|c|c|c|c|c|c|c|}
\hline & & $\begin{array}{l}\text { (https://cds.climate.copernicus. } \\
\text { eu/cdsapp\#!/home) }\end{array}$ & er 2020 & & & & \\
\hline 11 & $\mathrm{CO}_{2}$ & $\begin{array}{l}\text { Tropomi } \\
\text { (http://www.tropomi.eu) and } \\
\text { NBS, China } \\
\text { (http://www.stats.gov.cn/englis } \\
\text { h/) and European Centre for } \\
\text { Medium-Range Weather } \\
\text { Forecasts } \\
\text { (https://www.ecmwf.int) } \\
\text { and Sedac, NASA } \\
\text { (https://sedac.ciesin.columbia.e } \\
\text { du) }\end{array}$ & $\begin{array}{l}\text { January } \\
\text { to April } \\
\text { (2019 - } \\
2020)\end{array}$ & China & $-11.5 \%$ & & [23] \\
\hline 12 & $\mathrm{CO}_{2}$ & $\begin{array}{l}\text { Nondisper- } \\
\text { sive Infrared Spectroscopic } \\
\text { analyzer (NDIR) and Cavity Ring- } \\
\text { Down Spectroscopic analyzer } \\
\text { (CRDS) }\end{array}$ & $\begin{array}{l}01^{\text {st }} \\
\text { January } \\
1993 \text { to } \\
31^{\text {st }} \\
\text { March } \\
2020\end{array}$ & China & $\begin{array}{l}-(32 \pm \\
12 \%)\end{array}$ & & [24] \\
\hline 13 & $\mathrm{CO}$ & $\begin{array}{l}\text { Tropomi } \\
\text { (http://www.tropomi.eu) and } \\
\text { NOAA } \\
\text { (https://www.ospo.noaa.gov/Pr } \\
\text { oducts/atmosphere/soundings/i } \\
\underline{\text { asi/) and Copernicus }} \\
\text { (https://scihub.copernicus.eu) } \\
\text { and Aeris (https://iasi.aeris- } \\
\text { data.fr/cos iasi b arch/) } \\
\text { and Firms, NASA } \\
\text { (https://firms.modaps.eosdis.na } \\
\text { sa.gov) }\end{array}$ & $\begin{array}{l}\text { January } \\
\text { to May } \\
\text { (2019 - } \\
2020)\end{array}$ & China & & $-18.7 \%$ & [25] \\
\hline
\end{tabular}




\begin{tabular}{|c|c|c|c|c|c|c|}
\hline 14 & $\mathrm{CO}$ & $\begin{array}{l}\text { China National Environmental } \\
\text { Monitoring Centre } \\
\text { (http://www.cnemc.cn/en/) } \\
\text { and National Meteorological } \\
\text { Information Centre } \\
\text { (https://data.cma.cn/en) }\end{array}$ & $\begin{array}{l}23^{\text {rd }} \\
\text { January } \\
\text { to } 22^{\text {nd }} \\
\text { April } \\
(2019 \text { - } \\
2020)\end{array}$ & China & $-30 \%$ & [26] \\
\hline 15 & $\mathrm{CO}$ & $\begin{array}{l}\text { http://www.tianqihoubao.com/ } \\
\text { lishi/ }\end{array}$ & $\begin{array}{l}\text { January } \\
\text { to } \\
\text { March } \\
\text { (2017- } \\
2020)\end{array}$ & $\begin{array}{l}\text { Wuhan } \\
\text { Jingme } \\
\mathrm{n} \text {, and } \\
\text { Enshi } \\
\text { (China) }\end{array}$ & $-27.9 \%$ & [27] \\
\hline 16 & $B C$ & $\begin{array}{l}\text { Multiwavelength } \\
\text { Aethalometer }\end{array}$ & $\begin{array}{l}01^{\text {st }} \\
\text { January } \\
\text { to } 31^{\text {st }} \\
\text { March } \\
2020\end{array}$ & $\begin{array}{l}\text { Hangzh } \\
\text { ou, } \\
\text { China }\end{array}$ & $\begin{array}{l}-44 \% \\
(-1.1 \\
\left.\mu g / \mathrm{m}^{3}\right)\end{array}$ & [28] \\
\hline 17 & $\mathrm{CO}$ & $\begin{array}{l}\text { Shanghai Municipal Bureau of } \\
\text { Ecological Environment } \\
\text { (https://sthi.sh.gov.cn) }\end{array}$ & $\begin{array}{l}25^{\text {th }} \\
\text { Novemb } \\
\text { er } 2019 \\
\text { to } 22^{\text {nd }} \\
\text { May } \\
2020\end{array}$ & $\begin{array}{l}\text { Shangh } \\
\text { ai } \\
\text { Munici } \\
\text { pality, } \\
\text { China }\end{array}$ & $\begin{array}{l}\text { Declina } \\
\text { tion in } \\
\text { CO } \\
\text { concen } \\
\text { tration }\end{array}$ & [29] \\
\hline 18 & $\mathrm{CO}$ & $\begin{array}{l}\text { Gas Filter Correlation CO } \\
\text { Analyzer }\end{array}$ & $\begin{array}{l}\text { January } \\
\text { to } \\
\text { March } \\
2020\end{array}$ & $\begin{array}{l}\text { Hangzh } \\
\text { ou, } \\
\text { China }\end{array}$ & $-30 \%$ & [30] \\
\hline 19 & $\mathrm{CO}$ & $\begin{array}{l}\text { AirNow } \\
\text { (https://www.airnowtech.org) } \\
\text { and EPA } \\
\text { (https://www.epa.gov/outdoor- } \\
\text { air-quality-data) }\end{array}$ & $\begin{array}{l}\text { January } \\
\text { to April } \\
\text { (2017- } \\
2020)\end{array}$ & USA & $\begin{array}{l}\text { Declina } \\
\text { tion in } \\
\text { co } \\
\text { concen } \\
\text { tration }\end{array}$ & [32] \\
\hline
\end{tabular}




\begin{tabular}{|c|c|c|c|c|c|c|c|}
\hline 20 & $\mathrm{CO}$ & $\begin{array}{l}\text { Terra, NASA } \\
\text { (https://terra.nasa.gov/data/m } \\
\underline{\text { opitt-data) }} \\
\text { and Highway Performance } \\
\text { Monitoring System } \\
\text { (https://www.fhwa.dot.gov/poli } \\
\underline{\text { cyinformation/hpms/hpmsprim }} \\
\underline{\text { er.cfm) }} \\
\text { and NASA } \\
\text { (https://earthdata.nasa.gov/eos } \\
\underline{\text { dis/daacs/asdc) }}\end{array}$ & $\begin{array}{l}\text { March } \\
\text { to May } \\
\text { (2015- } \\
\text { 2019) }\end{array}$ & USA & & $\begin{array}{l}\text { Declina } \\
\text { tion in } \\
\text { co } \\
\text { concen } \\
\text { tration }\end{array}$ & [33] \\
\hline 21 & $\mathrm{BC}$ & $\begin{array}{l}\text { Tufts Air Pollution Monitoring } \\
\text { Lab and Airnow } \\
\text { (https://docs.airnowapi.org) }\end{array}$ & $\begin{array}{l}27^{\text {th }} \\
\text { March } \\
\text { to } 14^{\text {th }} \\
\text { May, } \\
2020\end{array}$ & $\begin{array}{l}\text { Somerv } \\
\text { ille } \\
\text { (USA) }\end{array}$ & & $\begin{array}{l}-(22- \\
46 \%)\end{array}$ & [34] \\
\hline 22 & $\mathrm{BC}$ & $\begin{array}{l}\text { Aethalometer and } \\
\text { https://www.worldweatheronli } \\
\underline{\text { ne.com }}\end{array}$ & $\begin{array}{l}3^{\text {rd }} \\
\text { January } \\
\text { to } 23^{\text {rd, }} \\
\text { March } \\
\text { and } 1^{\text {st }} \\
\text { April to } \\
14^{\text {th }} \\
\text { June } \\
2020\end{array}$ & $\begin{array}{l}\text { Jamshe } \\
\text { dpur, } \\
\text { India }\end{array}$ & $-80 \%$ & & [35] \\
\hline 23 & $\mathrm{BC}$ & Aethalometer & $\begin{array}{l}01^{\text {st }} \\
\text { January } \\
\text { to } 25^{\text {th }} \\
\text { May } \\
2020\end{array}$ & $\begin{array}{l}\text { Bengal } \\
\text { uru, } \\
\text { India }\end{array}$ & $-60 \%$ & & [38] \\
\hline 24 & $\mathrm{BC}$ & Aethalometer & $\begin{array}{l}18^{\text {th }} \\
\text { Februar } \\
\text { y to }\end{array}$ & $\begin{array}{l}\text { Delhi, } \\
\text { India }\end{array}$ & & $-78 \%$ & [39] \\
\hline
\end{tabular}




\begin{tabular}{|c|c|c|c|c|c|c|}
\hline & & & $\begin{array}{l}31^{\text {st }} \\
\text { July, } \\
2020\end{array}$ & & & \\
\hline 25 & $\mathrm{BC}$ & $\begin{array}{l}\text { ARFINET } \\
\text { (https://arfinet.vssc.gov.in/arfin } \\
\text { et/index.html) }\end{array}$ & $\begin{array}{l}25^{\text {th }} \\
\text { March } \\
\text { to } 31^{\text {st }} \\
\text { May, } \\
2020\end{array}$ & India & $\begin{array}{l}-(10- \\
40 \%)\end{array}$ & [43] \\
\hline 26 & $\mathrm{CO}$ & $\begin{array}{l}\text { MCD19A2 } \\
\text { (https://lpdaac.usgs.gov/produc } \\
\text { ts/mcd19a2v006/) and Sentinel } \\
\text { 5P } \\
\text { (https://sentinels.copernicus.eu } \\
\text { /web/sentinel/missions/sentine } \\
\text { l-5p) and EarthEngine } \\
\text { (https://earthengine.google.co } \\
\text { m) }\end{array}$ & $\begin{array}{l}\text { March } \\
\text { and } \\
\text { April } \\
(2019 \text { - } \\
2020)\end{array}$ & India & $\begin{array}{l}\text { Declina } \\
\text { tion in } \\
\text { co } \\
\text { concen } \\
\text { tration }\end{array}$ & [41] \\
\hline 27 & $\mathrm{CO}$ & $\begin{array}{l}\text { NASA (https://www.nasa.gov) } \\
\text { and World's Air Pollution } \\
\text { (https://waqi.info) }\end{array}$ & $\begin{array}{l}\text { January } \\
\text { to April } \\
\text { (2019- } \\
2020)\end{array}$ & India & $\begin{array}{l}\text { Reduce } \\
\text { d to } \\
10 p p m\end{array}$ & [42] \\
\hline 28 & $\mathrm{CO}$ & $\begin{array}{l}\text { CPCB } \\
\text { (https://app.cpcbccr.com/ccr/\#/ } \\
\text { caaqm-dashboard-all/caaqm- } \\
\text { landing) }\end{array}$ & $\begin{array}{l}16^{\text {th }} \\
\text { March } \\
\text { to } 14^{\text {th }} \\
\text { April } \\
\text { (2017- } \\
2020)\end{array}$ & India & $-10 \%$ & [40] \\
\hline
\end{tabular}




\begin{tabular}{|c|c|c|c|c|c|c|}
\hline 29 & $\mathrm{CO}$ & $\begin{array}{l}\text { CPCB } \\
\text { (https://app.cpcbccr.com/ccr/\#/ } \\
\text { caaqm-dashboard-all/caaqm- } \\
\text { landing) and World Population } \\
\text { Review } \\
\text { (https://worldpopulationreview } \\
\text {.com) }\end{array}$ & $\begin{array}{l}1^{\text {st }} \\
\text { March } \\
\text { to } 15^{\text {th }} \\
\text { April } \\
\text { (2019- } \\
2020)\end{array}$ & India & $\begin{array}{l}\text { Declina } \\
\text { tion in } \\
\text { CO } \\
\text { concen } \\
\text { tration }\end{array}$ & [44] \\
\hline 30 & $\mathrm{CO}$ & $\begin{array}{l}\text { CPCB } \\
\text { (https://app.cpcbccr.com/ccr/\#/ } \\
\text { caaqm-dashboard-all/caaqm- } \\
\text { landing) and NASA } \\
\text { (https://earthobservatory.nasa. } \\
\text { gov/images) and NOAA } \\
\text { (https://www.ncei.noaa.gov/pr } \\
\text { oducts/land-based- } \\
\text { station/integrated-surface- } \\
\text { database) and ESA } \\
\text { (https://www.esa.int/Applicatio } \\
\text { ns/Observing the Earth/Coper } \\
\text { nicus/) }\end{array}$ & $\begin{array}{l}1^{\text {st }} \\
\text { January } \\
\text { to } 17^{\text {th }} \\
\text { May } \\
(2017- \\
2020)\end{array}$ & India & $\begin{array}{l}16-46 \\
\%\end{array}$ & [45] \\
\hline 31 & $\mathrm{CO}$ & $\begin{array}{l}\text { WBPCB } \\
\text { (https://www.wbpcb.gov.in) } \\
\text { and LANDSAT } \\
\text { (https://www.usgs.gov/core- } \\
\text { science- } \\
\text { systems/nli/landsat/landsat- } \\
\text { satellite-missions?qt- } \\
\text { science support page related } \\
\text { con=0\#qt- } \\
\text { science support page related } \\
\underline{\text { con) }} \\
\text { and TROPOMI } \\
\text { (http://www.tropomi.eu/data- } \\
\text { products/mission-performance- }\end{array}$ & $\begin{array}{l}25^{\text {th }} \\
\text { March } \\
\text { to } 15^{\text {th }} \\
\text { May } \\
(2017- \\
2020)\end{array}$ & $\begin{array}{l}\text { Kolkata, } \\
\text { India }\end{array}$ & $-6.88 \%$ & [46] \\
\hline
\end{tabular}




\begin{tabular}{|c|c|c|c|c|c|c|c|}
\hline & & centre) & & & & & \\
\hline 32 & $\mathrm{CO}_{2}$ & $\begin{array}{l}\text { A three-dimensional sonic } \\
\text { anemometer and open-path } \\
\text { infrared gas analyzer and cavity } \\
\text { ring-down spectrometer }\end{array}$ & $\begin{array}{l}13^{\text {th }} \\
\text { January } \\
\text { to } 4^{\text {th }} \\
\text { June, } \\
2020\end{array}$ & $\begin{array}{l}\text { Florenc } \\
\text { e, Italy }\end{array}$ & $-62 \%$ & & [47] \\
\hline 33 & $\mathrm{CO}$ & $\begin{array}{l}\text { TROPOMI } \\
\text { (http://www.tropomi.eu/data- } \\
\text { products/level-2-products) } \\
\text { and MODIS } \\
\text { (https:///pdaac.usgs.gov/news/r } \\
\text { elease-of-modis-version-6- } \\
\text { maiac-data-products/) } \\
\text { and Copernicus } \\
\text { (https://sentinels.copernicus.eu } \\
\text { Lweb/sentinel/missions/sentine } \\
\text { l-1) }\end{array}$ & $\begin{array}{l}23^{\text {rd }} \\
\text { March } \\
\text { to } 15^{\text {th }} \\
\text { April } \\
\text { (2019- } \\
2020)\end{array}$ & $\begin{array}{l}\text { Pakista } \\
\mathrm{n}\end{array}$ & & $\begin{array}{l}\text { Declina } \\
\text { tion in } \\
\text { co } \\
\text { concen } \\
\text { tration }\end{array}$ & [48] \\
\hline 34 & $\mathrm{CO}$ & $\begin{array}{l}\text { Himawari } 8 \\
\text { (https://himawari8.nict.go.jp) } \\
\text { and AERONET } \\
\text { (https://aeronet.gsfc.nasa.gov) } \\
\text { and Environment department, } \\
\text { Malaysia } \\
\text { (https://www.doe.gov.my/port } \\
\text { alv1/en/) }\end{array}$ & $\begin{array}{l}18^{\text {th }} \\
\text { March } \\
\text { to } 30^{\text {th }} \\
\text { April } \\
(2018- \\
2020)\end{array}$ & $\begin{array}{l}\text { Malaysi } \\
\text { a }\end{array}$ & & $\begin{array}{l}-(25- \\
31 \%)\end{array}$ & [49] \\
\hline 35 & $\mathrm{CO}$ & $\begin{array}{l}\text { Korea Ministry of Environment } \\
\text { (https://www.airkorea.or.kr/we } \\
\text { b) }\end{array}$ & $\begin{array}{l}1^{\text {st }} \\
\text { Decemb } \\
\text { er to } \\
30^{\text {th }} \\
\text { April }\end{array}$ & Korea & & $\begin{array}{l}- \\
17.33 \\
\%\end{array}$ & [50] \\
\hline
\end{tabular}




\begin{tabular}{|c|c|c|c|c|c|c|}
\hline & & & $\begin{array}{l}\text { (2017- } \\
2020)\end{array}$ & & & \\
\hline 36 & $\mathrm{CO}_{2}$ & Six fast ferries & $\begin{array}{l}15^{\text {th }} \\
\text { March } \\
\text { to } 15^{\text {th }} \\
\text { June } \\
(2020)\end{array}$ & $\begin{array}{l}\text { sea } \\
\text { region } \\
\text { of } \\
\text { Spain } \\
\text { (Strait } \\
\text { of } \\
\text { Gibralt } \\
\text { ar) }\end{array}$ & $-10 \%$ & [51] \\
\hline 37 & $\mathrm{CO}_{2}$ & $\begin{array}{l}\text { MODIS } \\
\text { (https://modis.gsfc.nasa.gov/ab } \\
\text { out/) }\end{array}$ & $\begin{array}{l}6^{\text {th }} \text { April } \\
\text { to } 15^{\text {th }} \\
\text { Jun } \\
(2019 \text { - } \\
2020)\end{array}$ & $\begin{array}{l}\text { global } \\
\text { ocean }\end{array}$ & $-7 \%$ & [52] \\
\hline
\end{tabular}

The reports over the land and sea regions are reviewed and the findings depicted a clear picture of the steady decline of carbon emission/concentration around the world during the lockdown period. However, the extent of decrease is utterly different over land and sea. In contrast to the over-the-land reports, the rate of reduction is significantly lower over the sea due to the obvious reason of the limited provision of transportation through the sea and the carbon-absorbing phenomenon of the water bodies. Under these circumstances, the only possible source of carbon over the sea region can be the transported portion of it from the nearby land location. Moreover, the change in carbon emission/concentration is more significant in city/urban areas compared to the rural/remote region as both the vehicles and industries are dominant factors for the former one. It was also noticed that initially, the carbon emission/concentration was decreased with the immediate imposition of lockdown, but carbon emission/concentration gradually increases in the unlock phases as the people started to return to normal life. Thus the declining carbon emission/concentration during 
COVID-19 extends only temporary relief. Though the carbon emission/concentration reduced because of some unprecedented situations, however, it can be inferred that some specific strategies (e.g. work from home, bicycle to work, etc.) can be adopted by the concerned authorities to achieve reduced carbon emission/concentration and provide breathable air to the world.

${ }^{1}$ H. Damon Matthews et al., 'The Proportionality of Global Warming to Cumulative Carbon Emissions', Nature 459, no. 7248 (June 2009): 829-32, https://doi.org/10.1038/nature08047.

${ }^{2}$ Marilena Kampa and Elias Castanas, 'Human Health Effects of Air Pollution', Environmental Pollution, Proceedings of the 4th International Workshop on Biomonitoring of Atmospheric Pollution (With Emphasis on Trace Elements), 151, no. 2 (1 January 2008): 362-67, https://doi.org/10.1016/j.envpol.2007.06.012.

${ }^{3}$ OAR US EPA, 'Sources of Greenhouse Gas Emissions', Overviews and Factsheets, 29 December 2015, https://www.epa.gov/ghgemissions/sources-greenhouse-gas-emissions.

${ }^{4}$ Wei-jie Guan et al., 'Clinical Characteristics of Coronavirus Disease 2019 in China', New England Journal of Medicine, 28 February 2020, https://doi.org/10.1056/NEJMoa2002032.

5 'COVID-19 Map', Johns Hopkins Coronavirus Resource Center, accessed 11 August 2021, https://coronavirus.jhu.edu/map.html.

${ }^{6}$ Muhammad Abdullah et al., 'Exploring the Impacts of COVID-19 on Travel Behavior and Mode Preferences', Transportation Research Interdisciplinary Perspectives 8 (1 November 2020): 100255, https://doi.org/10.1016/j.trip.2020.100255.

${ }^{7}$ 'Changes in Transport Behaviour during the Covid-19 Crisis - Analysis', IEA, accessed 15 August 2021, https://www.iea.org/articles/changes-in-transport-behaviour-during-the-covid-19-crisis.

${ }^{8}$ Alexander W. Bartik et al., 'The Impact of COVID-19 on Small Business Outcomes and Expectations', Proceedings of the National Academy of Sciences 117, no. 30 (28 July 2020): 17656-66, https://doi.org/10.1073/pnas.2006991117.

${ }^{9}$ Andy Markowitz, '14 Iconic Retailers That Fell Into Pandemic Bankruptcy', AARP, accessed 15 August 2021, https://www.aarp.org/money/credit-loans-debt/info-2020/bankrupt-retail-chain-store-list-is-growing.html.

${ }^{10} \mathrm{Zhu}$ Liu et al., 'Near-Real-Time Monitoring of Global CO2 Emissions Reveals the Effects of the COVID-19 Pandemic', Nature Communications 11, no. 1 (14 October 2020): 5172, https://doi.org/10.1038/s41467-02018922-7.

${ }^{11}$ Zhu Liu et al., 'Carbon Monitor, a near-Real-Time Daily Dataset of Global CO2 Emission from Fossil Fuel and Cement Production', Scientific Data 7, no. 1 (9 November 2020): 392, https://doi.org/10.1038/s41597-02000708-7.

${ }^{12}$ Corinne Le Quéré et al., 'Temporary Reduction in Daily Global CO2 Emissions during the COVID-19 Forced Confinement', Nature Climate Change 10, no. 7 (July 2020): 647-53, https://doi.org/10.1038/s41558-020-0797$\mathrm{x}$.

${ }^{13}$ Vineet Singh Sikarwar et al., 'COVID-19 Pandemic and Global Carbon Dioxide Emissions: A First Assessment', Science of The Total Environment $794 \quad$ (10 November 2021): 148770, https://doi.org/10.1016/j.scitotenv.2021.148770.

${ }^{14}$ Christoph Bertram et al., 'COVID-19-Induced Low Power Demand and Market Forces Starkly Reduce CO2 Emissions', Nature Climate Change 11, no. 3 (March 2021): 193-96, https://doi.org/10.1038/s41558-02100987-x

15 Nikolaos Evangeliou et al., 'Changes in Black Carbon Emissions over Europe Due to COVID-19 Lockdowns', Atmospheric Chemistry and Physics 21, no. 4 (23 February 2021): 2675-92, https://doi.org/10.5194/acp-21-2675-2021.

${ }^{16}$ Piers M. Forster et al., 'Current and Future Global Climate Impacts Resulting from COVID-19', Nature Climate Change 10, no. 10 (October 2020): 1, https://doi.org/10.1038/s41558-020-0883-0.

${ }^{17}$ Robert Rapier, 'The World's Top 10 Carbon Dioxide Emitters', Forbes, accessed 24 August 2021, https://www.forbes.com/sites/rrapier/2019/12/04/the-worlds-top-10-carbon-dioxide-emitters/. 
${ }^{18}$ Xinxin Zhang, Zhenlei Li, and Jingfu Wang, 'Impact of COVID-19 Pandemic on Energy Consumption and Carbon Dioxide Emissions in China's Transportation Sector', Case Studies in Thermal Engineering 26 (1 August 2021): 101091, https://doi.org/10.1016/j.csite.2021.101091.

${ }^{19}$ Zhu Liu et al., 'Impact on China's CO2 Emissions from COVID-19 Pandemic', Chinese Science Bulletin 66, no. 15 (29 September 2020): 1912-22, https://doi.org/10.1360/TB-2020-0729.

${ }^{20}$ Qingqing Wang et al., 'Coronavirus Pandemic Reduced China's CO2 Emissions in Short-Term, While Stimulus Packages May Lead to Emissions Growth in Medium- and Long-Term', Applied Energy 278 (15 November 2020): 115735, https://doi.org/10.1016/j.apenergy.2020.115735.

${ }^{21}$ Pengfei Han et al., 'Assessing the Recent Impact of COVID-19 on Carbon Emissions from China Using Domestic Economic Data', Science of The Total Environment 750 (1 January 2021): 141688, https://doi.org/10.1016/j.scitotenv.2020.141688.

${ }^{22}$ Bo Zheng et al., 'Changes in China's Anthropogenic Emissions and Air Quality during the COVID-19 Pandemic in 2020', Earth System Science Data 13, no. 6 (17 June 2021): 2895-2907, https://doi.org/10.5194/essd-13-2895-2021.

${ }^{23}$ Bo Zheng et al., 'Satellite-Based Estimates of Decline and Rebound in China's CO2 Emissions during COVID-19 Pandemic', Science Advances 6, no. 49 (1 December 2020): eabd4998, https://doi.org/10.1126/sciadv.abd4998.

${ }^{24}$ Yasunori Tohjima et al., 'Detection of Fossil-Fuel CO2 Plummet in China Due to COVID-19 by Observation at Hateruma', Scientific Reports 10, no. 1 (29 October 2020): 18688, https://doi.org/10.1038/s41598-020-757636.

${ }^{25}$ Minqiang Zhou et al., 'Change of CO Concentration Due to the COVID-19 Lockdown in China Observed by Surface and Satellite Observations', Remote Sensing 13, no. 6 (January 2021): 1129, https://doi.org/10.3390/rs13061129.

${ }^{26}$ Tuo Zhang and Maogang Tang, 'The Impact of the COVID-19 Pandemic on Ambient Air Quality in China: A Quasi-Difference-in-Difference Approach', International Journal of Environmental Research and Public Health 18, no. 7 (January 2021): 3404, https://doi.org/10.3390/ijerph18073404.

${ }^{27}$ Kaijie Xu et al., 'Impact of the COVID-19 Event on Air Quality in Central China', Aerosol and Air Quality Research 20, no. 5 (2020): 915-29, https://doi.org/10.4209/aaqr.2020.04.0150.

${ }^{28}$ Liang Xu et al., 'Variation in Concentration and Sources of Black Carbon in a Megacity of China During the COVID-19 Pandemic', Geophysical Research Letters 47, no. 23 (2020): e2020GL090444, https://doi.org/10.1029/2020GL090444.

${ }^{29}$ Yang Bai et al., 'Changes in Air Quality during the First-Level Response to the Covid-19 Pandemic in Shanghai Municipality, China', Sustainability 12, no. 21 (January 2020): 8887, https://doi.org/10.3390/su12218887.

${ }^{30}$ Qi Yuan et al., 'Spatiotemporal Variations and Reduction of Air Pollutants during the COVID-19 Pandemic in a Megacity of Yangtze River Delta in China', Science of The Total Environment 751 (10 January 2021): 141820, https://doi.org/10.1016/j.scitotenv.2020.141820.

${ }^{31}$ Andrew Adewale Alola and Festus Victor Bekun, 'Pandemic Outbreaks (COVID-19) and Sectoral Carbon Emissions in the United States: A Spillover Effect Evidence from Diebold and Yilmaz Index', Energy \& Environment, 6 December 2020, 0958305X20977275, https://doi.org/10.1177/0958305X20977275.

${ }^{32}$ L. -W. Antony Chen et al., 'Nonuniform Impacts of COVID-19 Lockdown on Air Quality over the United States', Science of The Total Environment $745 \quad$ (25 November 2020): 141105, https://doi.org/10.1016/j.scitotenv.2020.141105.

${ }^{33}$ Yasin F. Elshorbany et al., 'The Status of Air Quality in the United States During the COVID-19 Pandemic: A Remote Sensing Perspective', Remote Sensing 13, no. 3 (January 2021): 369, https://doi.org/10.3390/rs13030369.

${ }^{34}$ Neelakshi Hudda et al., 'Reductions in Traffic-Related Black Carbon and Ultrafine Particle Number Concentrations in an Urban Neighborhood during the COVID-19 Pandemic', Science of The Total Environment 742 (10 November 2020): 19, https://doi.org/10.1016/j.scitotenv.2020.140931.

${ }^{35}$ Balram Ambade et al., 'Emission Reduction of Black Carbon and Polycyclic Aromatic Hydrocarbons during COVID-19 Pandemic Lockdown', Air Quality, Atmosphere \& Health 14, no. 7 (1 July 2021): 1081-95, https://doi.org/10.1007/s11869-021-01004-y.

36 Balram Ambade et al., 'COVID-19 Lockdowns Reduce the Black Carbon and Polycyclic Aromatic Hydrocarbons of the Asian Atmosphere: Source Apportionment and Health Hazard Evaluation', Environment, Development and Sustainability 23, no. 8 (1 August 2021): 12252-71, https://doi.org/10.1007/s10668-02001167-1. 
${ }^{37}$ A Ajay et al., 'Impact Assessment of Change in Anthropogenic Emissions Due to Lockdown on Aerosol Characteristics in a Rural Location', CURRENT SCIENCE 120, no. 2 (2021): 9.

${ }^{38}$ A Ajay et al., 'Impact of Lockdown-Related Reduction in Anthropogenic Emissions on Aerosol Characteristics in the Megacity, Bengaluru', CURRENT SCIENCE 120, no. 2 (2021): 9.

${ }^{39}$ Vikas Goel et al., 'Variations in Black Carbon Concentration and Sources during COVID-19 Lockdown in Delhi', Chemosphere 270 (1 May 2021): 129435, https://doi.org/10.1016/j.chemosphere.2020.129435.

${ }^{40}$ Shubham Sharma et al., 'Effect of Restricted Emissions during COVID-19 on Air Quality in India', Science of The Total Environment 728 (1 August 2020): 138878, https://doi.org/10.1016/j.scitotenv.2020.138878.

${ }^{41}$ Satya Prakash et al., 'Environmental Impact of COVID-19 Led Lockdown: A Satellite Data-Based Assessment of Air Quality in Indian Megacities', Urban Climate 38 (1 July 2021): 100900, https://doi.org/10.1016/j.uclim.2021.100900.

${ }^{42}$ N. Gupta, A. Tomar, and V. Kumar, 'The Effect of COVID-19 Lockdown on the Air Environment in India', Global Journal of Environmental Science and Management 6, no. Special Issue (Covid-19) (1 August 2020): 31-40, https://doi.org/10.22034/GJESM.2019.06.SI.04.

${ }^{43}$ Mukunda M Gogoi et al., 'Response of Ambient BC Concentration across the Indian Region to the NationWide Lockdown: Results from the ARFINET Measurements Of', CURRENT SCIENCE 120, no. 2 (2021): 11.

${ }^{44}$ Tejaswini Eregowda, Pritha Chatterjee, and Digvijay S. Pawar, 'Impact of Lockdown Associated with COVID19 on Air Quality and Emissions from Transportation Sector: Case Study in Selected Indian Metropolitan Cities', Environment Systems and Decisions, 9 March 2021, https://doi.org/10.1007/s10669-02109804-4.

${ }^{45}$ Yogesh Sathe et al., 'Surface and Satellite Observations of Air Pollution in India during COVID-19 Lockdown: Implication to Air Quality', Sustainable Cities and Society 66 (1 March 2021): 102688, https://doi.org/10.1016/j.scs.2020.102688.

${ }^{46}$ Biswajit Bera et al., 'Significant Impacts of COVID-19 Lockdown on Urban Air Pollution in Kolkata (India) and Amelioration of Environmental Health', Environment, Development and Sustainability 23, no. 5 (1 May 2021): 6913-40, https://doi.org/10.1007/s10668-020-00898-5.

${ }^{47}$ Stefania Venturi et al., 'Unveiling the Changes in Urban Atmospheric CO2 in the Time of COVID-19 Pandemic: A Case Study of Florence (Italy)', Science of The Total Environment 795 (15 November 2021): 148877, https://doi.org/10.1016/j.scitotenv.2021.148877.

${ }^{48}$ Ghaffar Ali et al., 'Environmental Impacts of Shifts in Energy, Emissions, and Urban Heat Island during the COVID-19 Lockdown across Pakistan', Journal of Cleaner Production 291 (1 April 2021): 125806, https://doi.org/10.1016/j.jclepro.2021.125806.

${ }^{49}$ Kasturi Devi Kanniah et al., 'COVID-19's Impact on the Atmospheric Environment in the Southeast Asia Region', Science of The Total Environment $736 \quad$ (20 September 2020): 139658, https://doi.org/10.1016/j.scitotenv.2020.139658.

${ }^{50}$ Min Jae Ju, Jaehyun Oh, and Yoon-Hyeong Choi, 'Changes in Air Pollution Levels after COVID-19 Outbreak in Korea', Science of The Total Environment $750 \quad$ (1 January 2021): 141521, https://doi.org/10.1016/j.scitotenv.2020.141521.

${ }^{51}$ Vanessa Durán-Grados et al., 'Calculating a Drop in Carbon Emissions in the Strait of Gibraltar (Spain) from Domestic Shipping Traffic Caused by the COVID-19 Crisis', Sustainability 12, no. 24 (January 2020): 10368, https://doi.org/10.3390/su122410368.

${ }^{52}$ Maryam R. Al Shehhi and Yarjan Abdul Samad, 'Effects of the Covid-19 Pandemic on the Oceans', Remote Sensing Letters 12, no. 4 (3 April 2021): 325-34, https://doi.org/10.1080/2150704X.2021.1880658. 